No 3708

Studia nad Autorytaryzmem i Totalitaryzmem 38, nr 1

Wrocław 2016

DOI: $10.19195 / 2300-7249.38 .1 .5$

JOANNA SONDEL-CEDARMAS

Uniwersytet Jagielloński

\title{
Czy Mussolini był butny? Refleksje wokół pewnej biografii Benita Mussoliniego ${ }^{1}$
}

W 2002 r. w książce pt. Fascismo. Storia e interpretazione włoski historyk Emilio Gentile zwracał uwagę na wzrost zainteresowania w ostatnich latach problematyką włoskiego faszyzmu, a zarazem tendencją, obecną zarówno we współczesnej historiografii, jak i publicznej debacie, do „defaszyzacji reżimu Mussoliniego", to znaczy przedstawiania jego ,ugrzecznionej wersji” jako pozbawionego cech totalitarnych i znacznie łagodniejszego w porównaniu z dyktaturami Stalina czy Hitlera ${ }^{2}$. Przykładem tego właśnie zjawiska jest moim zdaniem książka pt. Mussolini. Butny faszysta, która w 2015 r. pojawiła się na polskim rynku wydawniczym. Jej autor, szwedzki pisarz i publicysta Göran Hägg — jak sam zaznaczył we wstępie — ,zainteresował się Mussolinim 25 lipca 1993 roku [...] i żeby przybliżyć szwedzkim czytelnikom sylwetkę oraz osiągnięcia faszystowskiego Duce, postanowił nauczyć się języka włoskiego". Hägg podkreśla, że zarówno w Szwecji, jak i w krajach anglosaskich rozpowszechniony jest wizerunek Mussoliniego jako człowieka „o cokolwiek komicznej naturze” czy „słabszej kopii Hitlera” (s. 7-8). Książka nie rości sobie pretensji, aby „pokazać nowy materiał albo przedstawić własne oceny autora [...]”, lecz ma na celu „zaprezentowanie istniejącej wiedzy w oparciu o lekturę głównie włoskich materiałów, które dla przeciętnego szwedzkiego czytelnika są niedostępne" (s. 8-9). Dąży do przedstawienia systemu rządów Mussoliniego w sposób obiektywny, „bez nieporozumień i uprzedzeń" wynikających z nieznajomości włoskiej kultury i języka. W rzeczywistości od pierwszych jej stron odniosłam wrażenie, że autor stara się

1 G. Hägg, Mussolini. Butny faszysta, Warszawa 2015.

2 Zob. E. Gentile, Fascismo. Storia e interpretazione, Roma-Bari 2002. Podobnie o fascynacji totalitaryzmami w ostatnich latach pisał P. Betts, The New Fascination with Fascism: The Case of Nazi Modernism, „Journal of Contemporary History”, październik 2002. 
odbrązowić wizerunek włoskiego duce, a przez częste porównania go z Hitlerem i Stalinem próbuje ukazać „ludzką twarz” faszystowskiego reżimu.

Książka obejmuje okres od 1883 r. do 1945 r. i składa się z pięciu dużych części, które odpowiadają przełomowym etapom w życiu Benita Mussoliniego. Pierwsza część pt. Marsz po władzę pod czerwonym sztandarem obejmuje lata 1883-1919, od momentu narodzin przyszłego duce 29 lipca 1883 r. aż do utworzenia w Mediolanie w marcu 1919 r. ruchu faszystowskiego Fasci di combattimento. Autor interesująco przedstawia historię rodu Mussolinich, korzystając zarówno ze współczesnych opracowań historycznych, jak i z oficjalnych biografii faszystowskiego przywódcy z okresu dwudziestolecia, a mianowicie książki Dux autorstwa dziennikarki i wieloletniej przyjaciółki Mussoliniego - Margherity Sarfatti, biografii brata Vita di Arnaldo, napisanej przez samego duce, oraz propagandowego szkicu Personalità di Mussolini z 1941 r. Barwnie opisuje dzieciństwo oraz młodość Mussoliniego w Predappio, a przede wszystkim ewolucję jego poglądów od zbliżenia do partii socjalistycznej, współpracy z lewicowymi dziennikami „Il Popolo” oraz „La lotta di classe”, objęcia stanowiska naczelnego redaktora głównego organu socjalistów „Avanti!” w Mediolanie oraz aresztowania za kampanię przeciwko wojnie libijskiej, aż do przejścia na stronę interwencjonistów w 1914 r., porzucenia PSI i założenia dziennika „Il Popolo d'Italia”. Szwedzki publicysta łączy koniec pierwszego etapu w życiu Mussoliniego nie tyle z odejściem od socjalistów po wybuchu I wojny światowej, ile z momentem założenia Fasci di combattimento w 1919 r.

Część druga pt. Czarne koszule obejmuje kluczowy okres w historii włoskiego faszyzmu, to znaczy od utworzenia Związków Kombatanckich w Mediolanie 23 marca 1919 r., przez Marsz na Rzym i przejęcie władzy we Włoszech w październiku 1922 r., aż po zabójstwo sekretarza socjalistów-unitarystów Giacomo Matteottiego i wprowadzenie państwa totalnego w styczniu 1925 r. Autor dokładnie opisuje okoliczności powstania ruchu faszystowskiego na tle trudnej sytuacji politycznej i społecznej Włoch w okresie tzw. czerwonego dwulecia (19181920), falę rozczarowania „kalekim zwycięstwem”, wyprawę fiumeńską Gabriele D'Annunzia, trudną sytuację gospodarczą, bezrobocie i strajki robotnicze, wzrost znaczenia partii socjalistycznej i lewicowych związków zawodowych przy zupełnej nieudolności sprawującej władzę partii liberalnej, a w szczególności premiera Francesca Saveria Nittiego, który — jak słusznie zauważa Hägg - miał za zadanie ,administrować kruchym pokojem” i przygotować kraj do nowych wyborów. W trzech rozdziałach (Czarne koszule, Kto bierze władzę i Marsz na Rzym) szwedzki publicysta przedstawia dalszą ewolucję idei politycznych Mussoliniego w kierunku prawicowym oraz porzucenie pierwotnych koncepcji rewolucyjno-republikańskich, opracowanie metod działania bojówek faszystowskich (squadri$s t i)$ aż po zapewnienie poparcia dla ruchu ze strony konserwatywnych środowisk bogatej burżuazji i ziemiaństwa. Autor nie najlepiej prezentuje jednak moim zdaniem różnorodny ideologicznie charakter faszyzmu w latach 1922-1925, 
w którego łonie współistniało kilka odmiennych nurtów, począwszy od konserwatywnej prawicy byłych nacjonalistów, liberalno-konserwatywnego stronnictwa Massima Rocca, rewizjonistów Giuseppego Bottaia, idealistów Giovanniego Gentilego aż po syndykalistów rewolucyjnych i najbardziej radykalny odłam republikańsko-rewolucyjny Roberta Farinacciego ${ }^{3}$, a także masowy charakter partii faszystowskiej oraz rolę, jaką odegrało Stowarzyszenie Nacjonalistów Włoskich (które połączyło się z PNF w lutym 1923 r.) w zapewnieniu poparcia dla planowanego Marszu na Rzym ze strony króla Wiktora Emanuela III, sztabu wojska, części parlamentarzystów oraz hierarchii kościelnej. Przedstawiając natomiast proces przekształcania autorytarnej władzy Mussoliniego w kierunku totalitarnym w latach 1924-25, autor słusznie wiąże tę transformację z kryzysem, który ogarnął państwo po zamordowaniu socjalistycznego posła Giacoma Matteottiego i z powstaniem opozycji awentyńskiej w czerwcu $1924 \mathrm{r}$.

Trzecia część książki pt. Mussolini ma zawsze rację dotyczy rządów duce w latach 1925-1936, w okresie największej jego popularności, masowego poparcia dla systemu, a zarazem umacniania instytucji państwa totalitarnego, budowania systemu korporacyjnego, polityki wychowania „nowego człowieka”, powszechnego kultu faszystowskiego wodza oraz rozbudowanego aparatu propagandowego, przy jednoczesnym demontażu systemu wielopartyjnego, walce z przeciwnikami politycznym, likwidacji wolności prasy i reformy sądownictwa. Hägg zwraca uwagę na te elementy, które różniły faszystowskie Włochy od Trzeciej Rzeszy Adolfa Hitlera i Związku Radzieckiego Józefa Stalina i wpłynęły na określanie Włoch w literaturze jako „totalitaryzm niepełny”4, do którego cech należy zaliczyć łagodniejsze traktowanie przeciwników politycznych, przyznanie pewnej autonomii panującej monarchii, niektórym sferom kultury oraz Kościołowi. Osobiście podzielam pogląd Emilia Gentilego, że w 1938 r. wraz z przyjęciem ustaw rasistowskich proces totalitaryzacji faszystowskiego państwa uległ przyspieszeniu i resztki autonomii, którymi cieszyły się Kościół katolicki, monarchia i sfery kultury tak czy inaczej zostałyby zlikwidowane ${ }^{5}$. Nie ulega jednak wątpliwości, że rozwiązanie kwestii rzymskiej, to znaczy naprawienie trudnych relacji utrzymujących się między Stolicą Apostolską a państwem włoskim od 1870 r. przez zawarcie traktatów laterańskich w lutym 1929 r. stanowiło ukoronowanie zabiegów Mussoliniego o zapewnienie powszechnego poparcia społecznego dla jego polityki oraz zbudowania prestiżu na arenie międzynarodowej.

Kolejny etap w życiu Mussoliniego rozpoczyna się zdaniem Hägga w 1936 r. Nieprzypadkowo to właśnie zwycięska wojna w Etiopii w 1936 r., która stanowiła

3 Zob. E. Gentile, Le origini dell'ideologia fascista (1918-1925), Bologna 1996, s. 284 n.

4 Zob. J.W. Borejsza, Wstep, [w:] idem, Faszyzmy europejskie (1922-1945), Warszawa 1979, s. $18-19$.

5 Zob. E. Gentile, Saggio introduttivo, [w:] A.a. V.v., Il totalitarismo alla conquista della Camera alta. Inventari e documenti, Archivio storico del Senato della Repubblica, Cosenza 2002, s. 102. 
urzeczywistnienie marzeń o zmyciu plamy hańby pod Aduą w 1896 r., kultywowanych od ponad 30 lat przez włoskie środowiska nacjonalistyczne, chociaż zapewniła Mussoliniemu wielką popularność nie tylko wśród zwolenników, lecz nawet wrogów politycznych we Włoszech, doprowadziła jednocześnie do wprowadzenia przez Ligę Narodów sankcji gospodarczych i ostatecznie do zacieśnienia stosunków z Adolfem Hitlerem (rozmowy Ciano-Ribbentrop z 23 października 1936 r.).

W czwartej części książki pt. Czy Mussolini zawsze ma rację?, obejmującej lata 1936-1943, autor przedstawia stopniowy upadek potęgi faszystowskiego wodza, spowodowany jego błędnymi posunięciami w polityce zarówno wewnętrznej, jak i zagranicznej, do których zalicza przyjęcie ustaw rasistowskich w 1938 r., przystąpienie Włoch do paktu antykominterowskiego oraz udział w II wojnie światowej po stronie Niemiec. Interesująco opisuje ewolucję stosunków z Adolfem Hitlerem i zmianę postrzegania niemieckiego dyktatora przez duce od momentu objęcia przez niego urzędu kanclerza 30 stycznia 1933 r. (Hydraulik $w$ przeciwdeszczowym płaszczu) przez wzajemne relacje w okresie sankcji gospodarczych po wojnie abisyńskiej, uczestnictwo w hiszpańskiej wojnie domowej (Facetta nera, bell'Abissina oraz Sankcje, gaz i wojenna sława) i w czasie II wojny światowej. Hägg nie zgadza się z opinią anglosaskich historyków Denisa Macka Smitha i Richarda Boswortha, iż wojna abisyńska była politycznym błędem Mussoliniego, ani z tezą włoskiego historyka Renza De Felice, że Mussolini około 1936 r. padł ofiarą manii wielkości i uwierzył własnej propagandzie. Wiąże raczej błędne posunięcia $\mathrm{z}$ drugiej połowy lat 30 . z samotnością duce, spowodowaną utratą zaufanych doradców i przyjaciół, m.in. brata Arnalda, pierwszego sekretarza PNF oraz wiernego doradcy Michele Bianchiego, czy wspomnianej już Margherity Sarfatti, oraz z próbą zastąpienia ich rzeszą pochlebców, którzy „przysłaniali mu prawdziwy obraz sytuacji” (s. 248).

Według szwedzkiego publicysty ostatni etap w życiu Mussoliniego przypadł na lata 1943-1945. W piątej części książki pt. Państwo hańby autor przybliża najważniejsze wydarzenia, które doprowadziły do ostatecznej klęski faszystowskiego przywódcy, począwszy od decyzji Wielkiej Rady Faszystowskiej o odwołaniu Mussoliniego w nocy z 24 na 25 lipca 1943 r. i zaaresztowaniu dzień później z rozkazu króla Wiktora Emanuela III, po okoliczności jego uwolnienia przez niemieckich spadochroniarzy i utworzenie na północy Włoch marionetkowego państwa w pełni uzależnionego od Trzeciej Rzeszy — Włoskiej Republiki Społecznej. Zdaniem Hägga do 24 lipca 1943 r. Mussolini miał na sumieniu dwie sprawy: 1) użycie gazów w czasie wojny w Etiopii i 2) wprowadzenie ustaw rasowych. Jak podkreśla jednak, na ustawach rasistowskich widniał podpis króla Wiktora Emanuela III, a za użycie gazów w Etiopii współodpowiedzialny był marszałek Pietro Badoglio. Za bezdyskusyjne akty, które przypieczętowały los Mussoliniego 25 kwietnia 1945 r., autor uważa jednak dopiero przestępstwa popełnione po jego powrocie do władzy we wrześniu 1943 r., a mianowicie: 1) utworzenie obozów internowania i koncentracyjnych dla włoskich Żydów oraz zgoda na masowe 
wywożenie ich do hitlerowskich obozów zagłady $\left.{ }^{6}, 2\right)$ bezwzględna walka $\mathrm{z}$ antyfaszystowskim ruchem oporu i 3) masakry ludności cywilnej dokonywane przez oddziały SS oraz faszystów republikanów (tzw. repubblichini) w północnych Włoszech w latach 1944-1945.

Ostatni rozdział książki, pt. Powrót faszyzmu, poświęcony jest polityce rozrachunku z faszyzmem we Włoszech po 1945 r., a w szczególności tworzeniu i działalności ruchów neofaszystowskich na czele z Movimento Sociale Italiano w okresie I i II Republiki.

Należy podkreślić, że autor interesująco przedstawia losy Mussoliniego na tle sytuacji politycznej i społecznej Włoch od momentu zjednoczenia w $1861 \mathrm{r}$. do 1945 r. oraz w relacji z innymi wybitnymi osobowościami tej epoki, między innymi liberalnym premierem sprawującym rządy w latach 1903-1914 — Giovannim Giolittim, wybitnym poetą, pisarzem, dramaturgiem oraz największym konkurentem politycznym Mussoliniego w okresie poprzedzającym Marsz na Rzym - Gabriele D'Annunzinem czy przywódcą futurystów Filippo Tommaso Marinettim. Część spostrzeżeń Hägga uważam jednak za zbyt powierzchowne, a niektóre wyciągnięte przez niego wnioski za błędne. W szczególności w rozdziale poprzedzającym pierwszą część książki, pt. Co to jest Italia?, autor, opisując trudną sytuację młodego państwa włoskiego w drugiej połowie XIX w., wynikającą z rozdrobnienia Półwyspu Apenińskiego pod względem zarówno geograficznym, jak i kulturowym, mocno rozbudowany lokalny patriotyzm (campanilismo), przy niewykształconej świadomości narodowej, słabość instytucji politycznych połączoną z nieudolnością rządzącej dynastii sabaudzkiej i wrogością Kościoła do nowego państwa, zacofanie gospodarcze, problem emigracji przede wszystkim z regionów południowych oraz załamanie się polityki kolonialnej Francesca Crispiego w Afryce po klęsce pod Aduą w 1896 r., stwierdza, że termin „risorgimento" używany w literaturze na określenie zjednoczenia Włoch jest błędny. Jak zauważa, ,przed 1861 rokiem żadne zjednoczone państwo włoskie nie istniało, a większą część Półwyspu Apenińskiego udało się zjednoczyć w czasie wojny domowej 1860-1861" (s. 17). Hägg zapomina, że tego terminu używa się nie tylko na oznaczenie samego procesu zjednoczeniowego Włoch pod względem terytorialnym i politycznym, lecz także na określenie szerszego ruchu kulturalnego

${ }^{6}$ Ogólne wytyczne w kwestii zaostrzenia polityki rasistowskiej przyjęto na pierwszym kongresie Republikańskiej Partii Faszystowskiej w Weronie w dniach 14-16 listopada 1943 r. Na mocy artykułu 7. Manifestu werońskiego (tzw. Carta di Verona) „przynależących do rasy żydowskiej” uznano za „cudzoziemców” i traktowano jako „narodowość wrogą” w czasie trwającej wojny. Najważniejszymi obozami na terytorium północno-centralnych Włoch były: Fossoli di Carpi koło Modeny, Borgo San Dalmazzo (Cuneo) oraz Gries w Bolzano. Odmienny charakter miał obóz La Risiera di San Sabba znajdujący się na terytorium Adriatische Küstenland, powstały na przełomie października i listopada 1943 r. którym kierował Höherer SS und Polizeiführer Odilo Globocnik. Jest on uważany za jedyny prawdziwy obóz koncentracyjny we Włoszech i określony mianem „Polizei-Haftlager”. Zob. S. Pyciński, Małzeństwa mieszane w faszystowskich Włoszech (1938-1945), SnFiZH XXV, Wrocław 2002, s. 241-251. 
i ideologicznego, który narodził się w środowisku włoskich polityków i intelektualistów już pod koniec XVIII w. ${ }^{7}$ Zdaje się pomijać fakt, że risorgimento było wynikiem długiego i skomplikowanego procesu, w którym doszło do zderzenia się różnych programów ideologicznych. Ogólnikowo wspomina jedynie o „rewolucjonistach" (s. 21), czyli tzw. nurcie demokratyczno-republikańskim reprezentowanym przez Giuseppe Mazziniego i Giuseppe Garibaldiego, o wkładzie w dzieło zjednoczenia premiera Królestwa Sardynii hrabiego Camilla Benso di Cavour, nie wspominając nic o koncepcjach konfederalistycznych neogwelfistów Vincenza Giobertiego, Antonia Rosminiego, Cesara Balbo czy programie federalistycznym Carla Cattaneo, Giuseppe Ferrariego czy Carla Pisacanego. Podobnie też trudno jest mi zgodzić się z twierdzeniem autora, że etniczny nacjonalizm, który rozwinął się w Europie Północnej pod koniec XIX wieku w nowym państwie włoskim nie znalazł podatnego gruntu. Hägg zauważa, iż „w społeczeństwie włoskim nie występują typowe dla innych nacjonalizmów ujemne cechy nacjonalizmu", o czym świadczy tolerancyjne nastawienie wobec cudzoziemców ze strony Włochów, którzy „od średniowiecza byli przyzwyczajeni do pielgrzymów i podróżnych”, czy „brak wspólnoty narodowej pod jednym, narodowym sztandarem" (s. 19). Takie stwierdzenie należy uznać za nie tylko niezwykle upraszczające złożoną kwestię powstania i rozwoju nacjonalizmu we Włoszech, lecz wręcz za błędne. Autor nie dostrzega różnicy między nacjonalizmem demokratycznym pierwszej połowy XIX w., typowym dla okresu risorgimenta, który cechował kosmopolityzm, demokratyzm i liberalizm, a także pozytywne podejście do innych ruchów narodowowyzwoleńczych, zgodnie z hasłem walki „za wolność naszą i waszą", a agresywnym, imperialistycznym, antydemokratycznym, opierającym się na idei państwa narodowego oraz zasadniczo skierowanego przeciwko innym narodom nacjonalizmem, który rozwijał się od końca XIX w. i w pierwszym dwudziestoleciu XX w. Nacjonaliści integralni, jak Enrico Corradini, Francesco Coppola, Alfredo Rocco, pod wyraźnym wpływem darwinizmu społecznego rozwijali koncepcję wyższości własnego narodu, ideę rasy włoskiej „stirpe romana”, jednocześnie kultywując wizję zbudowania spójnej wspólnoty narodowej i opierając relacje z innymi narodami na sile, potędze własnego narodu i konflikcie zbrojnym.

7 Z historycznego punktu widzenia oznacza on ruch narodowościowy, który rozpoczął się po rewolucji francuskiej wraz z interwencją Napoleona Bonaparte we Włoszech w 1796 r. i miał na celu uwolnienie północnej części Półwyspu Apenińskiego spod panowania Austrii. W potocznym znaczeniu terminu tego używa się na określenie procesu zjednoczenia Włoch, który w przybliżeniu obejmuje okres od kongresu wiedeńskiego w 1815 r. do proklamowania Królestwa Włoch w 1861 r., a w szerszym spektrum do 1870 r. czy nawet 1871 r., to znaczy do zdobycia Rzymu i ogłoszenia tego miasta stolicą Włoch. Niektórzy historycy ograniczają ramy czasowe włoskiego risorgimenta od roku 1848 (obejmując trzy wojny o niezależność: pierwsza w latach 1848-1849, drugą w 1859 r. i trzecią w 1866 r.) aż do zdobycia Lacjum w 1870 r. E. Gentile, Italiani senza padri. Intervista sul Risorgimento, red. S. Fiori, Roma-Bari 2011, s. 8. 
Podobnie też w rozdziale pt. Rzady Proroka, w którym zostały przedstawione złożone relacje łączące Gabriele D’Annunzia i Benita Mussoliniego w okresie okupacji przez poetę miasta Fiume (1919-1920), autor analizując konstytucję państwa fiumeńskiego, Carta del Carnaro, będącą dziełem wspólnym anarchosyndykalisty Alceste De Ambrisa i D'Annunzia, stwierdza, iż „kształt tej ustawy zasadniczej stał się fundamentem dyskutowanego wielokrotnie włoskiego korporacjonizmu” oraz „wzorem dla przyszłej demokracji korporacyjnej” Mussoliniego (s. 101). Pomijając kwestię zdecydowanie antydemokratycznego systemu rządów zarówno D'Annunzia w okresie fiumeńskim, jak i Mussoliniego po przejęciu władzy we Włoszech, chciałam zauważyć, że zasadniczy fundament korporacjonizmu przyjętego w faszystowskich Włoszech stanowił nie model zaproponowany w konstytucji fiumeńskiej, lecz koncepcje korporacyjne nacjonalisty, ministra sprawiedliwości i wyznań w faszystowskim rządzie, Alfreda Rocco, które zostały przedstawione już w 1914 r. na III kongresie nacjonalistycznym w Mediolanie. Nie jestem także w stanie zrozumieć, dlaczego włoskie słowo Il Vate, to znaczy „Wieszcz”, często używane w literaturze do podkreślenia zasług literackich D'Annunzia, uważanego za jednego z najwybitniejszych poetów włoskich na przełomie XIX i XX w., zostało przetłumaczone przez autora jako „Prorok” (m.in. na s. 77, 104-111, 126, $135 \mathrm{i}$ innych).

Pewne wątpliwości budzi także rozdział pt. Rasizm i ostatni triumf, w którym Hägg przedstawia okoliczności wprowadzenia polityki rasistowskiej we Włoszech w 1938 r., a w szczególności stwierdzenie, że „Żydzi we Włoszech nie byli zintegrowani ze społeczeństwem" (s. 279). Faktem jest, że z początkiem lat 20. we Włoszech żyło stosunkowo niewielu Żydów, niemniej jednak zamieszkiwali oni Półwysep Apeniński już od starożytności, w okresie wczesnego średniowiecza istniały duże gminy żydowskie m.in. na Sycylii, w Rzymie, Apulii i w Benewencie, a dodatkowo w latach 1492-1494 znaleźli tam schronienie Żydzi sefardyjscy uciekający z terytoriów Hiszpanii i Portugalii. Chociaż w wielu miastach w XVI w. zmuszeni byli do zamieszkania w gettach ${ }^{8}$, od momentu zjednoczenia otrzymali jednak pełnię praw obywatelskich ${ }^{9}$ i przez cały okres Włoch liberalnych (1861-1922) brali aktywny udział w życiu politycznym, społecznym

8 Pierwsze getto dla Żydów powstało w Wenecji w 1516 r. Żydom włoskim nakazywała mieszkanie w gettach bulla papieża Pawła IV Cum nimis absurdum z 14 lipca 1555 r.

9 Proces emancypacji włoskich Żydów, rozpoczęty w niektórych państwach północnych Włoch w drugiej połowie XVIII w., m.in. w Wielkim Księstwie Toskanii od 1768 r. czy na terytoriach podległych Austrii (patent tolerancyjny Józefa II z 1781 r.), był kontynuowany w okresie napoleońskim i risorgimenta. Zakończył się wraz z utworzeniem Królestwa Włoch w $1861 \mathrm{r}$. W 1870 r. po przyłączeniu miasta Rzym do Królestwa Włoch zamknięto ostatnie we Włoszech getto — rzymskie. Należy pamiętać, że we Włoszech liberalnych obowiązywało równouprawnienie kultów, a Żydzi mieli warunki, żeby spełnić wymogi niezwykle rygorystycznego prawa wyborczego z 17 marca 1848 r.: w znakomitej większości umieli pisać i czytać (w 1861 r. jedynie 5,8\% Żydów włoskich było analfabetami, podczas gdy wśród katolików było ich aż 54\%), posiadali odpowiedni cenzus majątkowy oraz odpowiednie kwalifikacje majątkowe. Historyk Cecil Roth w dziele pt. The 
i kulturalnym kraju ${ }^{10}$. Wielu z nich żyło w mieszanych małżeństwach. Podobnie też stosunek faszystowskich władz do Żydów aż do 1938 r. należy uznać za pozytywny, o czym świadczy choćby cytowany przez autora wywiad Mussoliniego z Emilem Ludwigiem w 1932 r., a także fakt, że wśród najbliższych współpracowników duce nie brakowało osób pochodzenia żydowskiego. Wystarczy wspomnieć nazwiska Guido Junga, ministra finansów w latach 1932-1935 (nie od 1935 r. — jak podaje Hägg, s. 280), Gino Ariasa - wybitnego ekonomisty i historyka prawa, Carla Foà - endokrynologa i fizjologa odznaczonego m.in. medalem Accademia Nazionale dei Lincei, Angelo Oliviero Olivettiego — jednego z teoretyków faszystowskiego syndykalizmu i korporacjonizmu czy Margheritę Grassini Sarfatti. Hägg, podobnie jak wielu historyków z lat 40., wiąże wprowadzenie ustaw rasowych skierowanych przeciwko włoskim Żydom w 1938 r. z zacieśnieniem stosunków z Trzecią Rzeszą i zapewnieniem sobie w ten sposób lepszych stosunków z „,nowymi przyjaciółmi” ${ }^{11}$. W spółcześni historycy podkreślają raczej, że główną odpowiedzialność za wprowadzenie leggi razziali we Włoszech ponosi sam Mussolini, a pewne idee rasistowskie występowały we Włoszech już przed 1938 r. ${ }^{12} \mathrm{~W}$ samej Partii Faszystowskiej nie brakowało antysemitów, jak Roberto Farinacci, który już w 1932 r. postulował wprowadzenie numerus clausus dla Żydów na uniwersytetach, Giovanni Preziosi - redaktor antysemickiego pisma „La Vita Italiana” i autor włoskiej wersji Protokołów Mędrców Syjonu z 1921 r., a następnie generalny inspektor do spraw rasowych w latach 1944-1945, historyk Paolo Orano czy filozof Julis Evola.

Wartość omawianej książki obniża także wiele błędów w słowach cytowanych z języka włoskiego czy wręcz błędów formalnych, jak na przykład: skrót

History of the Jews of Italy stwierdził, że po 1870 r. nie było kraju, w którym sytuacja Żydów byłaby lepsza. Zob. B. Segre, Gli ebrei in Italia, Firenze 2001.

10 Spośród włoskich Żydów pełniących ważne funkcje państwowe wystarczy wspomnieć Isacco Pesaro Maurogonato, który w 1873 r. został wybrany na wiceprezydenta Izby Deputowanych i sprawował tę funkcję aż 5 kadencji; Luigiego Luzzato, ministra skarbu w 1892 r. i w latach 1896-1898; Ernesto Nathana — Żyda i masona, w 1907 r. wybranego burmistrza Rzymu; Elia Morpurgo - wiceministra poczty i telegrafu w latach w 1906 r. i 1910 r., a następnie wiceministra przemysłu i handlu (1916-1917 i 1917-1919); Giuseppe Toeplitza — założyciela Włoskiego Banku Komercyjnego, generała, senatora i ministra wojny (1902-1903); Giuseppe Ottolenghiego; pisarzy Itala Svevo i Alberto Moravię; wydawcę Emilia Trevesa; znanego antropologa Cesarego Lombroso, profesora prawa na uniwersytecie w Padwie: Vittoria Polacco czy Gabriele Pincherlego — współtwórcę reformy kodeksu karnego.

11 Zob. Pentad, The Remaking of Italy, London 1941, s. 103; E. Momigliano, Storia tragica e grottesca del razzismo fascista, Milano 1946, s. 48; P. Badoglio, L'Italia durante la seconda guerra mondiale, Milano 1946, s. 92.

12 Politykę rasistowską w koloniach włoskich zaczęto stosować po podboju Etiopii w 1935 r., kiedy to wypowiedziano wojnę tzw. małżeństwom mieszanym. Zob. D. Cantimori, Prefazione, [w:] R. De Felice, Storia degli ebrei italiani sotto il fascismo, Torino 2006 s. XXII; L. Salvatorelli, G. Mira, Storia d'Italia nel periodo fascista, Torino 1957, s. 753; G. Valabrega, Il fascismo e gli ebrei: appunti per un consuntivo storiografico, [w: Il fascismo e le autonomie locali, red. S. Fontana, Bologna 1973, s. 103; U. Caffaz, L'antisemitismo italiano sotto il fascismo, Firenze 1975, s. 2-3. 
Partito Nazionale Fascista to „PNF”, nie „PNE” (s. 128), a Movimento Sociale Italiano to „MSI”, nie „MAS” (s. 429); główna organizacja młodzieżowa w faszystowskich Włoszech nosiła nazwę „Balilla”, a nie „ballila” (s. 187); tytuł powieści Alessandra Manzoniego to I promessi sposi, nie I promes si sposi (s. 18); „La lotta di classe”, nie „La lotta di klasse” (s. 187); zawołanie bojowe oddziałów Arditi to „alalà", nie ,alala” (s. 116), a książka Il mito del sangue (Mit krwi) została napisana przez Juliusa Evolę, a nie pod wpływem Juliusa Evoli (s. 280). Takich przykładów można zacytować o wiele więcej. Podobnie też niektóre zwroty użyte w książce należy uznać za dość nieprecyzyjne czy wręcz niefortunne. Autor wspomina na przykład o „tajemniczym” (zapewne chodziło o „tajne”?) zebraniu Wielkiej Rady Faszystowskiej w Palazzo Venezia w nocy z 24 na 25 lipca 1943 r. czy „dziwnej” (?) wystawie w Rzymie w 2002 r. poświęconej Gabriele D’Annunziemu.

Moje wątpliwości budzi także wykorzystany materiał źródłowy. Oprócz ośmiotomowej biografii Mussoliniego autorstwa historyka Renza De Felice oraz opracowań anglosaskich badaczy Denisa Macka Smitha i Richarda Boswortha autor posługuje się biografiami, pamiętnikami i autobiografiami osób z otoczenia Mussoliniego, mowami i pismami politycznymi samego duce, a także powieściami, których akcja rozgrywa się we Włoszech w okresie dwudziestolecia międzywojennego. Nie korzysta z materiałów archiwalnych, prasy z okresu dwudziestolecia, a niektóre dane przytacza — jak sam stwierdził — z Wikipedii (!). Brak też jakichkolwiek odniesień do współczesnych znanych badaczy włoskiego faszyzmu, jak Emilio Gentile, Giovanni Sabbatucci, Giuseppe Parlato, Francesco Perfetti, Giorgio Rochat, Teodoro Sala, Michael A. Ledeen, Pierre Milza czy George L. Mosse.

Książka Hägga, chociaż barwnie przedstawia biografię faszystowskiego Duce, z uwzględnieniem mało znanych informacji z jego życia prywatnego, a w szczególności licznych romansów, nie jest pracą naukową, lecz raczej popularnonaukową. Czytelników chcących gruntowanie poznać doktrynę oraz system polityczno-prawny faszystowskich Włoch odsyłam raczej do opracowań historyków i politologów od wielu lat zajmujących się tą problematyką, jak wspomniani już Emilio Gentile, Pierre Milza, George L. Mosse, Pier Giorgio Zunino, czy polskich badaczy: Wiesława Kozuba-Ciembroniewicza, Jerzego Wojciecha Borejszy i Stanisława Sierpowskiego.

\section{Bibliografia}

A.a. V.v., Il totalitarismo alla conquista della Camera Alta. Inventari e documenti, Archivio Storico del Senato della Repubblica, Rubbettino, Cosenza 2002.

Badoglio P., L Italia durante la seconda guerra mondiale, Mondadori, Milano 1946.

Betts P., The New Fascination with Fascism: The Case of Nazi Modernism, „Journal of Contemporary History", październik 2002.

Borejsza J.W., Faszyzmy europejskie (1922-1945), Czytelnik, Warszawa 1979. 
Caffaz U., L'antisemitismo italiano sotto il fascismo, La Nuova Italia, Firenze 1975.

Cantimori D., Prefazione, [w:] R. De Felice, Storia degli ebrei italiani sotto il fascismo, Einaudi, Torino 2006.

Gentile E., Fascismo. Storia e interpretazione, Laterza, Roma-Bari 2002.

Gentile E., Italiani senza padri. Intervista sul Risorgimento, red. S. Fiori, Laterza, Roma-Bari 2011.

Gentile E., Le origini dell 'ideologia fascista (1918-1925), Il Mulino, Bologna 1996.

Hägg G., Mussolini. Butny faszysta, Prószyński i S-ka, Warszawa 2015.

Momigliano E., Storia tragica e grottesca del razzismo fascista, Mondadori, Milano 1946.

Pentad, The Remaking of Italy, Harmondsworth, London 1941.

Pyciński S., Matżeństwa mieszane w faszystowskich Włoszech (1938-1945), SnFiZH XXV, 2002, s. 241-251.

Salvatorelli L., Mira G., Storia d Italia nel periodo fascista, Einaudi, Torino 1957.

Segre B., Gli ebrei in Italia, La Giuntina, Firenze 2001.

Valabrega G., Il fascismo e gli ebrei: appunti per un consuntivo storiografico, [w:] Il fascismo e le autonomie locali, red. S. Fontana, Il Mulino, Bologna 1973.

\section{WAS MUSSOLINI ARROGANT? \\ REFLECTIONS ON A BIOGRAPHY OF BENITO MUSSOLINI}

\section{Summary}

The article is a review of a book by the Swedish writer and journalist Göran Hägg entitled Mussolini. En studie i makt published in Poland in 2015 as Mussolini. Butny faszysta [Mussolini. An Arrogant Fascist]. By focusing on elements which distinguished Mussolini's dictatorship from Adolf Hitler's Third Reich and Joseph Stalin's Soviet Union, Hägg subscribes to the view, present in contemporary historiography, that the Italian version of totalitarianism was "incomplete". Stressing the mass support for the regime in 1925-1936, the author links the Duce's gradual fall from power to mistakes in internal and foreign policy in the second half of the 1930 s, especially to the adoption of the racist laws of 1936 as well as Italy's accession to the Anti-Comintern Pact and participation in the Second World War on Germany's side. What the author considers to have been unquestionably misguided moves which sealed the fate of the Italian leader on 25 April 1945 were his decisions taken during the existence of the Italian Social Republic, namely: 1) creation of internment and concentration camps for Italian Jews; 2) ruthless fight against the anti-fascist resistance movement; and 3) massacres of civilians by SS troops and fascist republicans in northern Italy in 1944-1945.

Keywords: Benito Mussolini, fascism, Italian Social Republic, Göran Hägg.

Joanna Sondel-Cedarmas

e-mail: joanna.sondel@gmail.com 